УДК 656.078

UDK 656.078

Біліченко В.В., Романюк С.О., Цимбал С.В., Бабій С.М.

Вінницький національний технічний університет

\title{
РОЗРОБКА СТРАТЕГІЙ ТА ПРОЕКТІВ ІННОВАЦІЙНОГО РОЗВИТКУ ОРГАНІЗАЦІЙ АВТОПЕРЕВІЗНИКІВ
}

В статті обгрунтовано особливість роботи організацій автоперевізників та необхідність їх розвитку 3 активним використанням інновацій. Необхідність постійного і цілеспрямованого інноваційного розвитку організацій автоперевізників визначає їх успішну присутність на ринку, ефективну експлуатацію та отримання прибутку. Боротьба за транспортні ринки, високий попит споживачів на послуги автомобільних перевезень, статус інших транспортних компаній, які пропонують подібні послуги, необхідність оновлення та модернізації рухомого складу, виробничої та технічної бази вимагають від організацій автомобільних перевізників постійного розвитку та вдосконалення. Виходячи зі світового досвіду, можна стверджувати, що підприємства можуть активно розвиватися, раціонально використовувати всі види ресурсів базуючи свою діяльність на інноваціях.

Для ефективного впровадження інноваційної діяльності, а також зменшення ризиків, які $з$ нею пов'язані, пропонується використати інструменти та методологію стратегій розвитку та проектів їх реалізації. Розроблені актуальні стратегії інноваційного розвитку для конкретної організації автоперевізника. Практичну реалізацію інноваційних проектів та стратегій пропонується здійснити за допомогою динамічного моделювання, що дасть можливість визначити оптимальну стратегію розвитку підприємства на довгостроковий період за критерієм максимуму очікуваного доходу.

За допомогою програмного забезпечення встановлено основні показники ефективності кожної стратегії. Для кожної стратегії розроблений проект її реалізації.

Для опису та аналізу інноваційних проектів на передінвестиційному етапі використовувалось спеціалізоване програмне забезпечення для фінансового аналізу проектів, яке дозволило виконати оцінки основних показників проекту в цілому та обгрунтовувати ефективність інвестицій.

Для вибору оптимального проекту використовувався метод динамічного програмування, який дозволяє визначити оптимальну стратегію розвитку підприємства на довгострокову перспективу (в нашому завданні протягом 5 років) за критерієм максимального очікуваного доходу. Методологічною основою моделі $\epsilon$ теорія стохастичних процесів прийняття рішень та динамічного програмування.

Ключові слова: інноваційний розвиток, організація автоперевізника, стратегія, проект, динамічне програмування.

\section{ВСТУП}

В умовах становлення нових економічних відносин, коли ринкова економіка набуває загального характеру в Україні, проходять процеси, які призводять до змін структури ринку, - одні галузі розвиваються, а інші - занепадають. Транспортна система - одна 3 не багатьох систем господарювання, яка впливає на розвиток народного господарства всієї країни. Призначення автомобільного транспорту забезпечувати ефективне функціонування економіки. В свою чергу присутня конкуренція серед організацій перевізників на ринку, автомобільний транспорт потребує залучення інвестицій, впровадження нових методів управління, інноваційних проектів розвитку.

Рівень розвитку та ефективна діяльність організацій автоперевізників визначає якісний розвиток всієї автотранспортної галузі та рівня перевезень в Україні. Під організаціями автоперевізників будемо розуміти організації, які займаються пасажирськими (в рамках нашого дослідження) перевезеннями, крім того можуть виконувати технічний обслуговування та поточний ремонт автотранспортних засобів на власній виробничотехнічній базі.

Провівши аналіз робіт організацій автоперевізників $[1,2]$, можна виділити основні тенденції, а саме на сьогодні в Україні в сегменті пасажирських автомобільних перевезень, за оцінками фахівців, діє понад 30 тис. суб'єктів господарювання, переважна більшість яких має до 10 одиниць транспортних засобів. Такі організації автоперевізників, не використовуючи, як правило, власної виробничо-технічної бази для проведення всього комплексу необхідних робіт щодо профілактичних та ремонтних впливів, передають відповідні роботи, повністю або частково, на аутсорсинг.

Вище вказані характеристики структури рухомого складу суттєво послаблюють конкурентні позиції дрібних автоперевізників за показниками витрат і якості технічної підготовки. В першу чергу, це пов'язано 3 дією ефекту масштабу який, в свою чергу, пов'язується із величиною виробничо-технічної бази організації автоперевізника і обсягом надаваних нею послуг. Крім того, вікова структура рухомого складу та його різномарочність може бути перепоною до передачі послуг з технічної підготовки на аутсорсинг через відсутність суб'єктів господарювання, які пропонують їх взагалі, або за ціною, яка буде зумовлювати низьку конкурентоспроможність кінцевої послуги - послуги 3 перевезення пасажирів. Відповідно, перед автоперевізниками в першу чергу дрібними, постає задача пошуку і реалізації стратегічних інноваційних рішень щодо підвищення ефективності процесів забезпечення працездатності пасажирських транспортних засобів та конкурентоспроможності послуг з перевезення для подальшої ефективної діяльності. 
Таким чином, актуальною науково-прикладною задачею є формування теоретичних і методологічних основ розробка стратегій та проектів інноваційного розвитку організацій автоперевізників. Вирішення цієї задачі має сприяти розв'язанню такої важливої проблеми національної економіки як підвищення ефективності та якості пасажирських автомобільних перевезень при додержанні постійно зростаючих, відповідно до міжнародних стандартів, вимог до надійності, транспортної безпеки, економічності, комфортності та екологічності в умовах зменшення концентрації рухомого складу.

\section{АНАЛІЗ ЛІТЕРАТУРНИХ ДАНИХ ТА ПОСТАНОВКА ПРОБЛЕМИ}

Проблеми економічного, стратегічного і інноваційного розвитку, управління проектами знайшли широке відображення в зарубіжній і вітчизняній економічній літературі [3-7]. У них розкрито різні сторони процесу розвитку підприємств, а також управління інноваційною діяльністю. Проте, критичний аналіз робіт, а також офіційних нормативних документів свідчить про недостатнє опрацьовування методологічних, а також деяких теоретичних аспектів управління стратегічним розвитком підприємства зокрема розробки системних моделей проектного управління стратегіями інноваційного розвитку організацій автоперевізників. Пропоновані моделі і методи управління розвитком або розглядають процес розвитку з однієї сторони, або висвітлюють лише загальні питання. Недостатньо розкриті в літературі методи управління розвитком на засадах інноваційного підходу. Необхідність розробки системного підходу до управління інноваційною діяльністю як чинника стратегічного розвитку організацій автоперевізників підтверджується і суперечливим досвідом здійснення даного процесу на практиці вітчизняних організацій та підприємств.

Ефективним інструментом впровадження та успішної реалізації інновацій в організаціях автоперевізників виступають інноваційні стратегії та проекти їх реалізації. В організаціях автоперевізників за інновації можуть виступати нові продукти (послуги), технології їх виготовлення (надання), нові методи організації перевезень, нові методи та форми організації виробництва (збуту), вихід на нові ринки, способи використання чи застосування продуктів (послуг), нові бізнес-моделі розвитку і успішної роботи організації [8].

Оптимальний вибір проектів інноваційного розвитку є однією із важливих функцій системи підтримки прийняття рішень в управлінні проектами. Система підтримки прийняття рішень - це комплекс статистичних, аналітичних і імітаційних моделей процесів і робіт та програмних засобів по проекту для підготовки рішень по його реалізації. Ціллю інформаційної системи підтримки прийняття рішень є організація і управління прийняттям рішень при розробці і реалізації проектів на основі сучасних технологій обробки інформації.

Важливою функцією системи прийняття рішень $є$ змістовна обробка даних у процесі розв'язання функціональних задач управління проектами з метою вибору оптимального рішення серед альтернативних варіантів.

Для опису і аналізу інноваційних проектів на передінвестиційній стадії застосовуються спеціалізоване програмне забезпечення фінансового аналізу проектів, яке дозволяє виконати оцінки основних показників проекту в цілому і обгрунтувати ефективність капіталовкладень.

Розроблені моделі та комп'ютерні алгоритми оптимального вибору проектів інноваційного розвитку дозволяють розширити та удосконалити існуючий арсенал програмного забезпечення систем підтримки прийняття рішень і застосовуватись у якості їх допоміжних засобів.

\section{ЦІЛІ ТА ЗАДАЧІ ДОСЛІДЖЕННЯ}

Задача прийняття рішень у виборі проектів інноваційного розвитку полягає у наступному. Керівництво організації при розробці проекту інноваційного розвитку, проводячи аналіз економічного стану організації автоперевізника та спостереження умов роботи аналогічних організацій та підприємств і застосовуючи наукові дані, дійшло висновку, що економічний стан організації у поточному році можна вважати залежним від його стану у попередньому році.

\section{РЕЗУЛЬТАТИ ДОСЛІДЖЕНЬ}

Перехідні ймовірності між станами випадкового процесу описуються марковським випадковим ланцюгом [9]. Структура доходів у цих процесах представляється матрицею, елементами якої є прибуток або доход, які виникають унаслідок переходів із одних станів в інші. Матриця перехідних імовірностей і матриця доходів залежать від варіантів рішення, які приймає керівництво організації. Стани організації в залежності від рівня іiі економічної ефективності (прибутковості) можна охарактеризувати за трьома станами марковського ланцюга (таблиця 1):

Таблиця 1 Три економічні стани підприємства

\begin{tabular}{|c|c|}
\hline Економічний стан підприємства & Стани системи \\
\hline Низький & $\mathrm{S}_{1}$ \\
Задовільний & $\mathrm{S}_{2}$ \\
Хороший & $\mathrm{S}_{3}$ \\
\hline
\end{tabular}

Метою задачі є визначення оптимальної стратегії прийняття рішень (вибору проектів інноваційного розвитку організації), яка максимізує очікуваний дохід від процесу у заданому періоді дії проекту.

Для практичної реалізації задачі було обрано одну з організацій автоперевізників у м. Вінниця. Після аналізу досліджуваної організації, їі діяльності, основних виробничих та фінансових показників, проведення маркетингових досліджень та SWOT-аналізу, можна прийти до висновку, що найбільш пріоритетними для 
підприємства є заміна та оновлення рухомого складу і, у зв'язку з цим, впровадження сучасних технологічних процесів технічного обслуговування та ремонту.

В залежності від цілей, які ставить перед собою керівництво на наступний період, організація автоперевізника (система) може застосовувати три можливих проекти реалізації інноваційних стратегій розвитку на наступний період (табличка 2).

Таблиця 2 Проекти реалізації інноваційних стратегій

\begin{tabular}{|l|l|}
\hline \multicolumn{1}{|c|}{ Номер проекту } & \multicolumn{1}{c|}{ Зміст проекту } \\
\hline Проект 1 & $\begin{array}{l}\text { У системі передбачається проведення заходів по впровадженню сучасних } \\
\text { технологічних процесів технічного обслуговування та ремонту, проведення заходів по } \\
\text { підвищенню ефективності потужностей виробничо-технічної бази без додаткових } \\
\text { iнвестицій. Зростання прибутку незначне. }\end{array}$ \\
\hline Проект 2 & $\begin{array}{l}\text { Оновлення рухомого парку автобусів за рахунок купівлі 5 Богдан А 0690, } \\
\text { інвестиції незначні. Передбачається більш значне зростання прибутку. }\end{array}$ \\
\hline Проект 3 & $\begin{array}{l}\text { Розвиток системи за рахунок заміна автобусів ПАЗ-4234 на автобуси Богдан А- } \\
\text { 1452 (Е-2) в кількості 12 одиниць, розширення об'ємів послуг і залучення більш } \\
\text { широкої кількості клієнтів. Передбачаються значні витрати та прибутки. }\end{array}$ \\
\hline
\end{tabular}

Імовірності переходів системи із одних станів у інші задаються матрицею Р:

Стан системи у $\left\{\begin{array}{l}\mathrm{S}_{1} \\ \mathrm{~S}_{2} \\ \mathrm{~S}_{3}\end{array} \quad \mathrm{P}=\left(\begin{array}{lll}\mathrm{p}_{11} & \mathrm{p}_{12} & \mathrm{p}_{13} \\ \mathrm{p}_{21} & \mathrm{p}_{22} & \mathrm{p}_{23} \\ \mathrm{p}_{31} & \mathrm{p}_{32} & \mathrm{p}_{33}\end{array}\right)\right.$

За рахунок вибору інших стратегіi

I керівництво організації може прийняти рішення змінити перехідні ймовірності $\mathrm{p}_{\mathrm{ij}}(\mathrm{i}, \mathrm{j}=1, \ldots, \mathrm{m})$. Наприклад, воно може прийняти рішення вкласти інвестиції у розвиток організації з метою покрашення іiї економічного стану, нарощуючи виробничі потужності.

Для того, щоб поставити задачу прийняття рішень на перспективу, керівництво організації пов'язує 3 переходом із одних станів у інші функцію доходу (або прибутку). Функція доходу визначає дохід за період планування в залежності від станів, між якими здійснюється перехід. За рахунок вибору різних стратегій функціонування організації керівництво може покращати іiі економічний стан, наприклад, за рахунок капіталовкладень на придбання нових провізних спроможностей.

Для постановки задачі прийняття рішень треба встановити довжину періоду, на який приймається рішення. Відповідно розглядаються задачі прийняття рішень із скінченним і нескінченним числом етапів. В обох випадках треба вибрати найкращий проект діяльності організації - вкладати чи не вкладати кошти при заданих результатах економічного аналізу стану організації. За критерій оптимізації доцільно прийняти максимум очікуваного доходу від реалізації вибраних проектів.

Розглянемо модель задачі прийняття рішень на основі методу динамічного програмування [10]. Припустимо, що керівництво організації має намір визначити стратегію управління організацією на $\mathrm{N}$ років. Воно зацікавлене у визначенні своєї стратегії поведінки (вкладати чи не вкладати кошти) для кожного року горизонту планування. Оптимальна поведінка у даному випадку визначається такою стратегією, при якій організація одержує найбільший очікуваний дохід через $\mathrm{N}$ років.

Поставлену задачу можна представити як задачу динамічного програмування керованих процесів із скінченим числом етапів N. Метод динамічного програмування грунтується на принципі оптимальності Р. Белмана [11], що визначає порядок покрокового розв'язування задачі за допомогою рекурентних обчислювальних процедур. Принцип оптимальності формулюється наступним чином: оптимальне керування має основоположну властивість - якими б не були початковий стан та прийняте початкове рішення, наступні рішення повинні утворювати оптимальне керування відносно стану, що виник в результаті попереднього рішення. Отже, динамічне програмування $є$ поетапним плануванням багатокрокового процесу з оптимізацією на один крок, яке враховує на кожному кроці розвитку процесу загалом, тобто при прийнятті рішення враховується майбутнє процесу [12]. Безпосередньо це зробити неможливо, і власне, принцип оптимальності дає можливість розв'язувати багатоетапні задачі. 
Розглянемо алгоритм розв'язання поставленої задачі - оптимальний вибір інноваційних проектів функціонування організації протягом $\mathrm{N}$ років. Нехай задана матриця $\mathrm{C}=\left[\mathrm{C}_{\mathrm{ij}}\right], \mathrm{i}, \mathrm{j}=1, \ldots$, m вартостей переходів системи із стану $\mathrm{S}_{\mathrm{i}}$ у стан $\mathrm{S}_{\mathrm{i}}$ за один крок. Позначимо через $\mathrm{U}(\mathrm{n})=\left\{\mathrm{U}_{1}(\mathrm{n}), \mathrm{U}_{2}(\mathrm{n}), \ldots, \mathrm{U}_{\mathrm{m}}(\mathrm{n})\right\}$ вектор, який визначає дохід системи на кожному $\mathrm{n}-м y$ кроці $(\mathrm{n}=1, \ldots, \mathrm{N}) \mathrm{N}$ - крокового процесу. Якщо система, виходячи із стану $\mathrm{S}_{\mathrm{i}}$ за $\mathrm{n}$ кроків досягла стану $\mathrm{S}_{\mathrm{i}}$, то очікуваний оптимальний дохід можна визначити за допомогою прямого функціонального рівняння динамічного програмування у вигляді:

$$
\mathrm{U}_{\mathrm{i}}(\mathrm{n})=\max _{\mathrm{k}}\left\{\sum_{\mathrm{j}=1}^{\mathrm{m}}\left[\mathrm{C}_{\mathrm{ij}}^{\mathrm{k}}+\mathrm{U}_{\mathrm{j}}(\mathrm{n}-1)\right] \mathrm{p}_{\mathrm{ij}}^{\mathrm{k}}\right\} ; \mathrm{i}=1, \ldots, \mathrm{m} ; \mathrm{n}=1, \ldots, \mathrm{N},
$$

де $\mathrm{p}_{\mathrm{ij}}^{\mathrm{k}}-$ імовірності переходу системи $\mathrm{i}$ с стану $\mathrm{S}_{\mathrm{i}}$ y $\quad$ стан $\mathrm{S}_{\mathrm{j}} \quad(\mathrm{i}, \quad \mathrm{j} \quad=1, \ldots, \quad \mathrm{m}) \quad$ за k-м проектом (при альтернативі $\mathrm{k}(\mathrm{k}=1,2, \ldots, \mathrm{r})$ );

$\mathrm{C}_{\mathrm{ij}}^{\mathrm{k}}$ - оцінка переходу із стану $\mathrm{S}_{\mathrm{i}}$ у стан $\mathrm{S}_{\mathrm{j}}$ при альтернативі $\mathrm{k}(\mathrm{k}=1,2, \ldots, \mathrm{r})$;

$\mathrm{U}_{\mathrm{i}}(\mathrm{n})$ - очікуваний сумарний дохід системи за $\mathrm{n}$ кроків $(\mathrm{n}=1, \ldots, \mathrm{N})$, якщо процес почався із стану $\mathrm{i}(\mathrm{i}=$ $1, \ldots, \mathrm{m})$.

Наведене рівняння грунтується на тому, що сумарній дохід $\mathrm{C}_{\mathrm{ij}}^{\mathrm{k}}+\mathrm{U}_{\mathrm{j}}(\mathrm{n}-1)$ отримується в результаті переходу системи у стан ј на етапі $\mathrm{n}-1$ із стану і на етапі n з імовірністю $\mathrm{p}_{\mathrm{ij}}^{\mathrm{k}}$.

Вираз (1) можна записати у вигляді:

$$
\mathrm{U}_{\mathrm{i}}(\mathrm{n})=\max _{\mathrm{k}}\left\{\mathrm{g}_{\mathrm{i}}^{\mathrm{k}}+\sum_{\mathrm{j}=0}^{\mathrm{m}} \mathrm{p}_{\mathrm{ij}}^{\mathrm{k}} \mathrm{U}_{\mathrm{j}}(\mathrm{n}-1)\right\},
$$

або у матричній формі

$$
\mathrm{U}(\mathrm{n})=\max _{\mathrm{k}}\left\{\mathrm{g}^{\mathrm{k}}+\mathrm{P}^{\mathrm{k}} \mathrm{U}_{\mathrm{j}}(\mathrm{n}-1)\right\},
$$

де $U(n)$ - вектор загального очікуваного доходу після $n$ кроків, $\mathrm{P}^{\mathrm{k}}=\left(\mathrm{p}_{\mathrm{ij}}^{\mathrm{k}}\right)$ - матриця ймовірностей переходів, $\mathrm{g}^{\mathrm{k}}=\left(\mathrm{g}_{\mathrm{i}}^{\mathrm{k}}\right)$ - вектор вартостей перебування системи у станах $\mathrm{S}_{\mathrm{i}}(\mathrm{i}, \mathrm{j}=1, \ldots, \mathrm{m})$ при вибраній стратегії $\mathrm{k}$ $(\mathrm{k}=1, . ., \mathrm{r})$, компоненти цього вектора дорівнюють $\mathrm{g}_{\mathrm{j}}^{\mathrm{k}}=\sum_{\mathrm{j}=0}^{\mathrm{m}} \mathrm{C}_{\mathrm{ij}}^{\mathrm{k}} \mathrm{p}_{\mathrm{ij}}^{\mathrm{k}}$.

Розглянуту модель задачі визначення оптимальної стратегії у процесах прийняття рішень в управління інноваційними проектами можна узагальнити у двох відношеннях. По-перше, перехідні ймовірності і функції доходу можуть бути різними у будь-який рік. По-друге, можна використовувати коефіцієнт дисконтування очікуваних доходів для послідовних етапів, у наслідок чого значення $\mathrm{U}_{\mathrm{i}}(\mathrm{N})$ будуть представляти собою приведенні величини очікуваних доходів по всіх етапах.

У першому випадку потрібно, щоб значення доходів $\mathrm{g}_{\mathrm{j}}^{\mathrm{k}} \mathrm{i}$ перехідні ймовірності $\mathrm{p}_{\mathrm{ij}}^{\mathrm{k}}$ були також функціями етапу n. Друге узагальнення полягає у наступному. Нехай $\alpha(\alpha<1)-$ річний коефіцієнт дисконтування, який зазвичай обчислюється за формулою $\alpha=1 /(1+\mathrm{t})$, де $\mathrm{t}-$ річна норма банківського відсотку. Таким чином, D гривень наступного року дорівнюють $\alpha \mathrm{D}$ гривням поточного.

У загальному випадку при дисконтуванні оптимальне рішення може відрізнятися від оптимального рішення без врахування дисконтування.

Рекурентне рівняння динамічного програмування можна використовувати для розв'язання задач прийняття рішень, для оцінки будь-якої стаціонарної стратегії. Припускаючи, що дисконтування не враховується, одержимо рекурентне рівняння для оцінки стаціонарної стратегії у вигляді

$$
U_{i}(n)=g_{i}+\sum_{j=1}^{m} p_{i j} U_{j}(n-1), n=2, \ldots, N,
$$

де $\mathrm{P}_{\mathrm{ij}}-(\mathrm{i}, \mathrm{j})$-й елемент матриці перехідних імовірностей, що відповідає оцінюваній стратегії, а $\mathrm{g}_{\mathrm{i}}-$ очікуваний доход за цією стратегією.

Елементи матриці C можуть бути обчислені як різниця середньорічного доходу $\mathrm{D}(\mathrm{Q})$ підприємства по роках періоду планування із $\mathrm{N}$ років і поточних витрат $\mathrm{C}(\mathrm{Q})$ з урахуванням приведених капітальних вкладень К, 
де Q - величина провізної спроможності парку транспортних засобів організації. Поточні витрати обчислюються за формулою:

$$
C(Q)=\sum_{j=1}^{N} \frac{C_{j}(Q)}{(1+K)^{j}}
$$

де $\mathrm{K}$ - вартість капіталу за інвестиційним проектом.

Матриці ймовірностей переходів визначаються на основі цілей, які передбачають розглядувані проекти розвитку організації, орієнтовані на досягнення станів $\mathrm{S}_{1}, \mathrm{~S}_{2}, \mathrm{~S}_{3}$.

Як сказано раніше, організація автоперевізника (система) може застосовувати три можливі стратегії (проекти) своєї поведінки на наступний період:

- 1-й проект - у системі передбачається проведення заходів по впровадженню сучасних технологічних процесів технічного обслуговування та поточного ремонту, проведення заходів по підвищенню ефективності потужностей виробничо-технічної бази без додаткових інвестицій. Зростання прибутку незначне;

- 2-й проект - оновлення рухомого парку автобусів за рахунок купівлі 5 Богдан А 0690, інвестиції незначні. Передбачається більш значне зростання прибутку;

- 3-й проект - заміна автобусів ПАЗ-4234 на автобуси Богдан А-1452 (Е-2) в кількості 12 одиниць, розширення об'ємів послуг і залучення більш широкої кількості клієнтів. Передбачаються значні витрати та прибутки.

За заданими матрицями ймовірностей переходів $\mathrm{P}_{1}, \mathrm{P}_{2}, \mathrm{P}_{3}$, які відповідають розглядуваним стратегіям $\mathrm{S}_{1}, \mathrm{~S}_{2}, \mathrm{~S}_{3}$ i матрицею вартостей переходів $\mathrm{C}$, знайдемо оптимальну стратегію управління проектом функціонування організації автоперевізника на період у $\mathrm{N}=5$ років і оцінимо іiї економічну ефективність за критерієм максимуму доходу.

Обчислюючи вектори $\mathrm{g}^{1}, \mathrm{~g}^{2}, \mathrm{~g}^{3}$ вартостей перебування системи у станах $\mathrm{S}_{1}, \mathrm{~S}_{2}, \mathrm{~S}_{3}$ за стратегіями $\mathrm{k}_{\mathrm{i}}(\mathrm{i}=1$, $2,3)$, оцінимо вартості переходів системи за $\mathrm{n}=1, \ldots, \mathrm{N}$ років. У розглядуваній задачі період у $\mathrm{N}=5$ років вибраний із міркувань, що за цей період система входить у стаціонарний режим функціонування і у подальші періоди іiі стани стабільні.

Початкові дані задачі:

- матриця вартостей переходів від поточного стану організації до станів, що відповідають стратегіям $\mathrm{k}_{\mathrm{i}}(\mathrm{i}=$ 1, 2, 3) дорівнює:

$$
C=\left(\begin{array}{ccc}
10 & 50 & 100 \\
100 & 200 & 250 \\
150 & 250 & 300
\end{array}\right)
$$

- матриці ймовірностей переходів за стратегіями $\mathrm{k}_{\mathrm{i}}(\mathrm{i}=1,2,3)$ мають вигляд:

$$
\mathrm{P}_{1}=\left(\begin{array}{lll}
0,8 & 0,15 & 0,05 \\
0,7 & 0,25 & 0,05 \\
0,6 & 0,35 & 0,05
\end{array}\right) ; \mathrm{P}_{2}=\left(\begin{array}{ccc}
0,01 & 0,8 & 0,18 \\
0,02 & 0,9 & 0,08 \\
0,05 & 0,9 & 0,05
\end{array}\right) ; \mathrm{P}_{3}=\left(\begin{array}{ccc}
0,02 & 0,08 & 0,9 \\
0,05 & 0,05 & 0,9 \\
0,01 & 0,09 & 0,9
\end{array}\right) ;
$$

За формулами (2) розраховуємо вартості перебування системи у станах $\mathrm{S}_{1}, \mathrm{~S}_{2}, \mathrm{~S}_{3}$ у відповідності з вибраними стратегіями

$$
\begin{aligned}
& \mathrm{m}=3 \text {, } \\
& \mathrm{r}=3, \quad \mathrm{~N}=\mathrm{mr}=9, \\
& i=1, \ldots m, \\
& \mathrm{k}=1, \ldots \mathrm{r} \\
& \mathrm{j}=1, \ldots \mathrm{n} . \\
& \mathrm{g} 1_{\mathrm{i}}:=\sum_{\mathrm{j}=1}^{\mathrm{m}} \mathrm{C}_{\mathrm{i}, \mathrm{j}} \cdot \mathrm{P} \mathrm{1}_{\mathrm{i}, \mathrm{j}} \\
& \mathrm{g} 2_{\mathrm{i}}:=\sum_{\mathrm{j}=1}^{\mathrm{m}} \mathrm{C}_{\mathrm{i}, \mathrm{j}} \cdot \mathrm{P} 2_{\mathrm{i}, \mathrm{j}} \mathrm{g} 3_{\mathrm{i}}:=\sum_{\mathrm{j}=1}^{\mathrm{m}} \mathrm{C}_{\mathrm{i}, \mathrm{j}} \cdot \mathrm{P} 3_{\mathrm{i}, \mathrm{j}} \\
& \mathrm{g} 1=\left(\begin{array}{c}
20.5 \\
132.5 \\
192.5
\end{array}\right) \\
& \mathrm{g} 2=\left(\begin{array}{c}
58.1 \\
202 \\
247.5
\end{array}\right) \\
& \mathrm{g} 3=\left(\begin{array}{l}
92.4 \\
240 \\
294
\end{array}\right)
\end{aligned}
$$

Вектор максимальних вартостей перебування системи у станах за стратегіями $\mathrm{k}_{\mathrm{i}}(\mathrm{i}=1,2,3)$, елементи якого визначаються як $\mathrm{V}_{1}:=\max \left(\mathrm{g} 1_{1}, \mathrm{~g} 2_{1}, \mathrm{~g} 3_{1}\right), \mathrm{V}_{2}:=\max \left(\mathrm{g} 1_{2}, \mathrm{~g} 2_{2}, \mathrm{~g} 3_{2}\right), \mathrm{V}_{3}:=\max \left(\mathrm{g} 1_{3}, \mathrm{~g} 2_{3}, \mathrm{~g} 3_{3}\right)$ дорівнює: $\mathrm{V}=(92,4 ; 240 ; 294)$.

Розрахунки параметрів оптимальних стратегій наведені у таблицях 3 i 4.

Таблиця 3 Оптимальні стратегії функціонування системи за моделлю динамічного програмування 
(C) Біліченко В.В., Романюк С.О., Цимбал С.В., Бабій С.М. 2020

\begin{tabular}{|c|c|c|c|c|c|c|c|}
\hline \multicolumn{2}{|c|}{ Стратегії } & $\begin{array}{l}\text { Роки } \\
\text { періоду }\end{array}$ & 1 & 2 & 3 & 4 & 5 \\
\hline \multirow{3}{*}{ 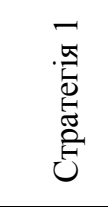 } & \multicolumn{2}{|c|}{ Стан $1 \mathrm{~W} 1_{1}$} & 94,2 & 146,6 & 196,1 & 245,2 & 294,2 \\
\hline & \multicolumn{2}{|c|}{ Стан $2 \mathrm{~W} 1_{2}$} & 240,0 & 273,1 & 320,8 & 369,6 & 418,6 \\
\hline & \multicolumn{2}{|c|}{ Стан $3 \mathrm{~W}_{1}$} & 294,0 & 347,7 & 393,4 & 442,1 & 491,1 \\
\hline \multirow{3}{*}{ 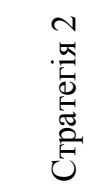 } & \multicolumn{2}{|c|}{ Стан $1 \mathrm{~W} 2_{1}$} & 94,2 & 304,0 & 502,8 & 703,2 & 903,5 \\
\hline & \multicolumn{2}{|c|}{ Стан 2 W2 $2_{2}$} & 240,0 & 443,4 & 645,8 & 848,1 & 1050,4 \\
\hline & \multicolumn{2}{|c|}{ Стан 3 W2 ${ }_{3}$} & 294,0 & 482,9 & 685,9 & 888,1 & 1090,4 \\
\hline \multirow{3}{*}{ 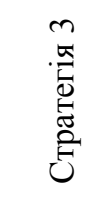 } & \multicolumn{2}{|c|}{ Стан $1 \mathrm{~W} 3_{1}$} & 94,2 & 304,0 & 570,4 & 857,0 & 1143,6 \\
\hline & \multicolumn{2}{|c|}{ Стан $2 \mathrm{~W} 3_{2}$} & 240,0 & 443,4 & 712,0 & 998,5 & 1285,1 \\
\hline & \multicolumn{2}{|c|}{ Стан $3 \mathrm{~W}_{3}$} & 294,0 & 482,9 & 771,6 & 1058,2 & 1344,8 \\
\hline \multicolumn{3}{|c|}{$\begin{array}{c}\text { Дохід за оптимальною стратегією } \\
\mathrm{U}_{\mathrm{i} \max }\end{array}$} & 294,0 & 482,9 & 771,6 & 1058,2 & 1344,8 \\
\hline \multicolumn{3}{|c|}{ Оптимальні стратегії k } & 3 & 3 & 3 & 3 & 3 \\
\hline
\end{tabular}

Таблиця 4 Порівняння стратегій

\begin{tabular}{|c|c|c|c|c|}
\hline \multirow{3}{*}{ Стратегії } & $\begin{array}{c}\text { Прирощення доходу між станами системи } \\
\text { останнього і попереднього періоду } \\
\text { фунціонування }\end{array}$ & $\begin{array}{c}\text { Прирощення доходу між станами системи у } \\
\text { кінці періоду функціонування }\end{array}$ \\
\hline \multirow{3}{*}{$S_{1}$} & $\Delta 1_{1}$ & 49 & $\Delta 1_{21}$ & 124,4 \\
\cline { 2 - 5 } & $\Delta 1_{2}$ & 49 & $\Delta 1_{31}$ & 196,9 \\
\cline { 2 - 5 } & $\Delta 1_{3}$ & 49 & $\Delta 1_{32}$ & 72,4 \\
\cline { 2 - 5 } & $\Delta 2_{1}$ & 203,3 & $\Delta 2_{21}$ & 146,9 \\
\cline { 2 - 5 }$S_{2}$ & $\Delta 2_{2}$ & 202,3 & $\Delta 2_{31}$ & 186,9 \\
\hline \multirow{3}{*}{$S_{3}$} & $\Delta 2_{3}$ & 202,2 & $\Delta 2_{32}$ & 141,6 \\
\cline { 2 - 5 } & $\Delta 3_{1}$ & 286,6 & $\Delta 3_{21}$ & 201,2 \\
\cline { 2 - 5 } & $\Delta 3_{2}$ & 286,6 & $\Delta 3_{31}$ & 59,7 \\
\hline
\end{tabular}

В таблиці 4 наведена різниця у вартості переходів між 1-м і 2-м, 1-м і 3-м та 2-м і 3-м станами після $\mathrm{n} \geq$ 5 кроків завжди дорівнює: у першому випадку приблизно 141,6 ум. гр. од., у другому 201,2 ум. гр. од., у третьому - 59,7 ум. гр. од.

Результати розрахунків показують, що оптимальною $\epsilon$ третя стратегія $\mathrm{k}_{3}$ - "організація автоперевізника вкладає великі інвестиції. За цією стратегією у порівнянні із стратегією $\mathrm{k}_{2}$ - "організація автоперевізника вкладає середні інвестиції" забезпечує дохід на 59,7 ум. гр. од. більше; за стратегією $\mathrm{k}_{3}$ - "організація автоперевізника вкладає великі інвестиції" у порівнянні із стратегією $\mathrm{k}_{1}$ - "організація автоперевізника вкладає незначні інвестиції" - на 201,2 ум. гр. од., за стратегією $\mathrm{k}_{2}$ - " організація автоперевізника вкладає середні інвестиції" у порівнянні із стратегією $\mathrm{k}_{1}$ - " організація автоперевізника вкладає незначні інвестиції" - на 141,6 ум. гр. од.

Таким чином, дана модель, використовуючи метод динамічного програмування, дозволяс визначити оптимальну стратегію розвитку організації автоперевізника на довгостроковий період (у нашій задачі на 5 років) за критерієм максимуму очікуваного доходу.

\section{ОБГОВОРЕННЯ РЕЗУЛЬТАТІВ ДОСЛІДЖЕНЬ}

Від рівня інноваційного розвитку організацій автомобільного транспорту (автоперевізників) залежить економічний та фінансовий стан не тільки автомобільної галузі, але й могутність регіонів і життєвий рівень населення.

Необхідність безперервного і цілеспрямованого інноваційного розвитку організацій автоперевізників визначає їх успішне перебування на ринку, ефективне функціонування і отримання прибутків. Боротьба за ринки перевезень, високі вимоги споживачів до автотранспортних послуг, статус інших транспортних підприємств, які пропонують аналогічні послуги, необхідність в оновленні й модернізації рухомого складу, виробничо-технічної бази вимагають від організацій автоперевізників постійного розвитку і вдосконалення. Спираючись на світовий досвід, можна стверджувати, що підприємства можуть активно розвиватися, при раціональному використанні всіх видів ресурсів та базуванню своєї діяльності на інноваціях. 
Ефективно впроваджувати інноваційну діяльність в організаціях автоперевізниках можливо при розробці стратегій інноваційного розвитку та проектів їх реалізації.

На прикладі конкретного організації автоперевізників у м. Вінниця та за допомогою SWOT-аналізу та маркетингових досліджень були виокремленні три пріоритетні для організації інноваційні стратегії та розроблені проекти їх реалізації: проект №1 - впровадження сучасних технологічних процесів технічного обслуговування та поточного ремонту, проект №2 - оновлення рухомого парку автобусів за рахунок купівлі 5 Богдан А 0690 та проект №3 - заміна автобусів ПАЗ-4234 на автобуси Богдан А-1452 (Е-2) в кількості 12 одиниць.

За допомогою програмного забезпечення були встановленні основні показники ефективності кожної стратегії. По кожній стратегії розроблений проект іiі реалізації.

Для вибору оптимального проекту використовується метод динамічного програмування, що дозволяє визначити оптимальну стратегію розвитку підприємства на довгостроковий період (у нашій задачі на 5 років) за критерієм максимуму очікуваного доходу. Методологічною основою моделі є теорія стохастичних процесів прийняття рішень та динамічне програмування.

Результати розрахунків показують, що оптимальною є третя стратегія k3 - "організація автоперевізника вкладає великі інвестиції".

\section{ВИСНОВКИ}

Запропонований в роботі методичний підхід з використанням динамічного моделювання дозволить організаціям автоперевізникам практично обирати для себе оптимальні стратегії та розробляти по ним проекти інноваційного розвитку та більш точно прогнозувати доходи у майбутньому з врахуванням змін та тенденцій зовнішнього та внутрішнього стану організації.

\section{ПЕРЕЛІК ДЖЕРЕЛ ПОСИЛАННЯ}

1. Біліченко В. В. Формування бачення продукту і результату проекту регіонального партнерства підприємств автомобільного транспорту у розвитку системи забезпечення працездатності пасажирських транспортних засобів / В. В. Біліченко, С. О. Романюк, Б. О.Петрук, Д. Г. Яновий // Вісник машинобудування та транспорту, 2015. - № 2- С. 8-14.

2. Романюк С. О. Визначення значень показників інноваційного рівня автотранспортних підприємств вінницької області / С. О. Романюк // Міжвузівський збірник «Наукові нотатки». - 2012. - Вип. 36. - С. 241-245.

3. Біліченко В. В. Системна модель проектного управління стратегіями розвитку організацій автомобільного транспорту за етапами їх життєвого циклу / В. В. Біліченко, С. О. Романюк // Вісник Вінницького політехнічного інституту. - 2013. - № 6. - С. 102-107. $340 \mathrm{c}$.

4. Ансофф И. Стратегический менеджмент. Классическое издание / Игорь Ансоф - СПб: Питер, 2009. -

5. Виханский О. С. Стратегическое управление / О. С. Виханский. - М. : Гардарики, 2002. - 296 с.

6. Томпсон А. Стратегический менеджмент / А. Томпсон, Д. Стрикленд. - М. : ЮНИТИ, 1998. - 576 с.

7. Сухарев О. С. Стратегия эффективного развития фирмы: ученик / О. С. Сухарев. - М. : Издательство «Экзамен», 2008. - 287 с.

8. Романюк С. О. Інноваційні процеси розвитку автотранспортних підприємств / С. О. Романюк // Вісник ЖДТУ. - 2008. - № III (46) Т. II. - С. 124-129.

9. Горбань I. I. Теорія ймовірностей і математична статистика для наукових працівників та інженерів / I. І. Горбань. - Київ, 2003. - С. 244.

10. Окулов С. М. Динамическое программирование / С. М. Окулов, О. А. Пестов - М.: Бином. Лаборатория знаний, 2012. - С. 296.

11. Беллман Р. Динамическое программирование / Р. Беллман. - М. : Изд-во «Иностранная литература», 1960. $-400 \mathrm{c}$.

12. Ройтенберг Я. Н. Автоматическое управление. Изд-во «Наука», Главная редакция физикоматематической литературы, М., 1971, С. 396.

\section{REFERENCES}

1. Bilichenko V. V., Romanyuk S. O., Petruk B.O., Yanovyy D. H. (2015) Formuvannya bachennya produktu i rezultatu proektu rehionalnoho partnerstva pidpryyemstv avtomobilnoho transportu u rozvytku systemy zabezpechennya pratsezdatnosti pasazhyrskykh transportnykh zasobiv, Visnyk mashynobuduvannya ta transportu, 2, 814.

2. Romanyuk S. O. (2012) Vyznachennya znachen pokaznykiv innovatsiynoho rivnya avtotransportnykh pidpryyemstv vinnytskoyi oblasti, Mizhvuzivskyy zbirnyk «Naukovi notatky», 36, 241-245.

3. Bilichenko V. V. Romanyuk S. O. (2013) Systemna model proektnoho upravlinnya stratehiyamy rozvytku orhanizatsiy avtomobilnoho transportu za etapamy yikh zhyttyevoho tsyklu, Visnyk Vinnytskoho politekhnichnoho instytutu, 6, 102-107.

4. Ansoff Y. (2009) Stratehycheskyy menedzhment. Klassycheskoe yzdanye, Pyter, 340.

5. Vykhanskyy O. S. (2002) Stratehycheskoe upravlenye. - M. : Hardaryky, 296.

6. Tompson A., Stryklend D. (1998) Stratehycheskyy menedzhment, 576. 
7. Sukharev O. S. (2008) Stratehyya effektyvnoho razvytyya fyrmy: uchenyk, -M. : Ekzamen, 287.

8. Romanyuk S. O. (2008) Innovatsiyni protsesy rozvytku avtotransportnykh pidpryyemstv, III (46), II, $124-129$.

9. Horban I. I. (2003) Teoriya ymovirnostey i matematychna statystyka dlya naukovykh pratsivnykiv ta inzheneriv, 244.

10. Okulov S. M., Pestov O.A. (2012) Dynamycheskoe prohrammyrovanye, Bynom. Laboratoryya znanyy, 296.

11. Bellman R., (1960) Dynamycheskoe prohrammyrovanye, Ynostrannaya lyteratura, 400.

12. Roytenberh Ya. N. (1971) Avtomatycheskoe upravlenye. Hlavnaya redaktsyya fyzyko-matematycheskoy lyteratury, 396.

\section{Bilichenko, S. Romanyuk, S. TsymbaL, S. Babiy. Working of innovation strategies and projects} development of carriers 'organizations.

The work describes the peculiarity of the work of trucking organizations and substantiates the need for their development with the active use of innovations. The need for continuous and purposeful innovative development of trucking organizations determines their successful presence on the market, efficient operation and profit. The struggle for transportation markets, high consumer demands for road transport services, the status of other transport companies that offer similar services, the need to update and modernize rolling stock, production and technical base require from the organizations of road carriers constant development and improvement. Based on world experience, it can be argued that enterprises can actively develop, with the rational use of all types of resources and basing their activities on innovation.

To effectively implement innovation, as well as reduce the risks associated with it, it is proposed to use the tools and methodology of development strategies and projects for their implementation. Current strategies of innovative development for a specific organization of the trucking company are developed. The practical implementation of innovative projects and strategies is proposed to be carried out using dynamic modeling, which will allow to determine the optimal strategy for the long-term development of the enterprise by the criterion of maximum expected income.

With the help of the software, the main indicators of the effectiveness of each strategy were established. A project for its implementation has been developed for each strategy.

To describe and analyze innovative projects at the pre-investment stage, specialized software for financial analysis of projects is used, which allows to perform assessments of the main indicators of the project as a whole and to justify the effectiveness of investments.

To select the optimal project, the method of dynamic programming is used, which allows to determine the optimal strategy of enterprise development for the long term (in our task for 5 years) by the criterion of maximum expected income. The methodological basis of the model is the theory of stochastic decision-making processes and dynamic programming.

Key words: innovative development, organization of trucker, strategy, project, dynamic programming.

БІЛІЧЕНКО Віктор Вікторович, доктор технічних наук, професор, завідувач кафедри автомобілів та транспортного менеджменту, Вінницький національний технічний університет е-таil: bilichenko.v@gmail.com

РОМАНЮК Світлана Олександрівна, кандидат технічних наук, доцент кафедри автомобілів та транспортного менеджменту, Вінницький національний технічний університет е-таil: romchuk.s85@gmail.com

ЦИМБАЛ Сергій Володимирович, кандидат технічних наук, доцент кафедри автомобілів та транспортного менеджменту, Вінницький національний технічний університет е-таil: tsymbals v @@ukr.net

$\overline{\bar{A}} \overline{\bar{D}} І$ Й Сергій Миколайович, кандидат технічних наук, доцент кафедри електромеханічних систем автоматизації в промисловості і на транспорті, Вінницький національний технічний університет e-mail: babiy82sm@gmail.com

Victor BILICHENKO, Doctor of Technical Science, Professor of Automobiles and Transport Management Department, Vinnytsya National Technical University e-mail: bilichenko.v@gmail.com

Svitlana ROMANYUK, PhD in Engeneering, Associate Professor of Automobiles and Transport Management Department, Vinnytsya National Technical University e-mail: romchuk.s85@gmail.com

Sergiy TSYMBAL, $\mathrm{PhD}$ in Engeneering, Associate Professor of Automobiles and Transport Management Department, Vinnytsya National Technical University e-mail: tsymbal_s_v@ukr.net

Sergiy $B A B I Y, \mathrm{PhD}$ in Engeneering, Associate Professor of Electromechanical Systems of Automation in Industry and Transport Department, Vinnytsya National Technical University e-mail: babiy82sm@gmail.com

DOI 10.36910/automash.v1i14.344 